\title{
HALFWAY HOUSES FOR ALCOHOL DEPENDENTS: FROM THEORETICAL BASES TO IMPLICATIONS FOR THE ORGANIZATION OF FACILITIES
}

\author{
Alessandra Diehl Reis, ${ }^{\mathrm{I}}$ Ronaldo Laranjeira ${ }^{\mathrm{II}}$ \\ doi: $10.1590 / \mathbf{S 1 8 0 7 - 5 9 3 2 2 0 0 8 0 0 0 6 0 0 0 2 0}$
}

\begin{abstract}
Reis AD, Laranjeira R. Halfway houses for alcohol dependents: from theoretical bases to implications for the organization of facilities. Clinics. 2008;63:827-32.

The purpose of this paper is to supply a narrative review of the concepts, history, functions, methods, development and theoretical bases for the use of halfway houses for patients with mental disorders, and their correlations, for the net construction of chemical dependence model. This theme, in spite of its relevance, is still infrequently explored in the national literature. The authors report international and national uses of this model and discuss its applicability for the continuity of services for alcohol dependents. The results suggest that this area is in need of more attention and interest for future research.
\end{abstract}

KEYWORDS: Halfway Houses; Alcohol-Related Disorders; Organization and Administration.

\section{INTRODUCTION}

Although there is no clear evidence of the direct influence of psychiatric therapeutic residence on mental illness, during the search for new approaches for treating chemical dependence, such models for treating the mentally ill were responsible for the increasing popularity of halfway houses in the USA (United States of America) and England in the 1970s for the treatment of alcohol- related problems. ${ }^{1,2}$

The purpose of this paper is to supply a narrative review of the historical, conceptual theoretical bases, functions, methods, and development of halfway houses, and to evaluate available evidence for their effectiveness and "successful" examples of halfway houses for patients with mental disorders and their correlation with the chemical dependence network construction.

\footnotetext{
I Psychiatry Department, Alcohol and Drugs Research Unit (UNIAD) - São Paulo/SP, Brazil.

II Federal University of São Paulo (UNIFESP), Escola Paulista de Medicina (EPM) - São Paulo/SP, Brazil.

Email: alediehl@terra.com.br

Tel.: 55115833.2838

Received for publication on June 19, 2008

Accepted for publication on July 23, 2008
}

\section{Halfway housing for persons with severe mental illness}

National publications on the subject are rare and hardly provide reliable evidence. They generally consist of case reports or quality studies with small convenience samples. Studies evaluating behavioral aspects, social skills, satisfaction and effectiveness of the Therapeutic Residences in the country are rare..$^{3,7,9,12}$

Halfway housing is a therapeutic approach that appeared in the USA in the 1960s, advanced by a group of people who worked in psychiatric hospitals and were looking for a new treatment modality for the mentally ill. The main objective in establishing such facilities was to provide a viable alternative to both large-scale psychiatric hospitals and small family environments to which severely mentally ill patients were sent once they were discharged..$^{1-3}$

The halfway housing system was implemented to alleviate the social isolation experienced by the mentally ill in communities; to demystify the universal medical model, in which patients are considered ill all of the time while in the hospital; and to provide a functional environment without imprisonment. Further, it aimed to recreate a home with its amenities and to allow the participants to get to know one another and coexist within the neighborhood, for example, by running errands, attending church and going for walks. ${ }^{1,2}$ 
Two conceptual theoretical models for halfway houses have been proposed: the family model and the social model. Residence function is based on a typical familiar group inserted in a social organization. ${ }^{1,2,4,6}$ Further, families are systems that operate through transitional rules originating from repeated interactions among individuals, while the social atmosphere proposes a therapeutic factor. ${ }^{4,6}$

In general, halfway houses are located in close proximity to psychiatric departments or health units for additional support. Approximately 10 to 15 people live in each house. Although initially staffed by volunteers who are, depending on the program, assisted by a professional team of social workers, nurses, occupational therapists and doctors, in the long term, halfway houses aim to be self-managed by residents. ${ }^{1,2}$ The volunteer staff and the professional team assist residents in crisis management, reagudization symptoms, medication use, meals and activities. Important issues are discussed in meetings with all "residents," who cease to be referred to as "patients," and the decision process is democratic. Residents visit doctors and therapists in an outpatient program. ${ }^{1,2}$

Halfway houses began to proliferate in other countries in the 1970s. Originally they were intended to address the needs of specific population groups, such as ex-convicts on parole, mentally ill homeless individuals, and women with mental problems who lacked social support. ${ }^{1,2,5}$ Meanwhile, in the midst of mental asylum negligence around the world, the Psychiatric Reform movement, started in Italy by the young field of Social Psychiatry, gained strength. The existence of the movement became noticeable after the endorsement of Law \#180 in 1978, which was motivated by Franco Basaglia's phenomenological ideas. ${ }^{3,7}$ Since then, modern Italian Therapeutic Residences have structured themselves as miniature psychiatric hospitals with an average of 12 beds. Girolamo (2002) relates the existence of 1,370 Therapeutic Residences in Italy to a total of 17,138 beds and a staff of 18,666 professionals involved. ${ }^{8}$ These numbers are important to keep in mind given the initial proposal of gradual deinstitutionalization.

The oldest halfway houses are the Rutland Corner House in Vermont for women and the Berkley House in Boston. A follow up study that evaluated 26 residences in the USA, including the two above, revealed that $20 \%$ of ex-patients were hospitalized, $58 \%$ were living independently and 55\% were employed or back in school. There was found to be general improvement in the degree of social adjustment and vocation interest, even in chronic patients. ${ }^{1,2}$

Brazil's first use of Therapeutic Residences began in the 1990s as a result of Act number 106/2000 (The Psychiatric Reform), which called for the implementation of Therapeutic Residences under the unified public health system. The new deinstitutionalization policy in Brazil, as in many countries, aimed to direct the mentally ill to Therapeutic Residences and emergency admissions to the psychiatric units of general hospitals while increasing outpatient service. ${ }^{7,9,11}$

According to data from 2004, there are 256 Service Therapeutic Residences in 45 cities in 14 states of Brazil. These services house approximately 1,400 mentally ill individuals with long asylum histories and without sufficient family or social resources to obtain appropriate care. ${ }^{11}$

The cost to maintain these residences in other countries is rather low. The estimated cost is US $\$ 12.00$ per day per patient, compared to a cost of US $\$ 100.00$ per hospital bed day in the USA. ${ }^{13}$ In Brazil, the government gives a one-time US\$6700.00 startup incentive to each Therapeutic Residence Service. These funds go toward small repairs to the house and basic amenities. For monthly expenses, revenue may reach US\$5000.00, which corresponds to a maximum of eight residents per residential module. ${ }^{11}$

Recently, Jacob et al. (2007), in a study of countries where mental health system information is available, revealed that existing mental health programs lack financial resources, policy, legislation and infrastructure and are inadequately staffed. ${ }^{14}$

Taking into consideration the facts above and studies that have consistently shown that five out of 10 of the most incapacitating morbidities in the world (measured through years lost due to disabilities) are mental disorders (e.g., alcohol dependence, schizophrenia, depression, bipolar disorder and obsessive compulsive disorder), ${ }^{15}$ it is appropriate to ask when mental health will be considered one of the main areas of public health, deserving of investment in research, prevention and specialized care.

In light of the issues described above, the lack of cost-benefit studies comparing the traditional model to new deinstitutionalization policies in Brazil has generated extensive criticism of the Psychiatric Reform proposal up to the present day. ${ }^{10,16,17}$

\section{METHODS}

This narrative review includes periodical articles obtained from primary data sources dating from 1960 to 2008, textbooks, and Masters' and Doctorate degree theses containing relevant information about halfway houses for alcohol dependents.

\section{RESULTS}

\section{Halfway houses for alcohol dependents}

It is important to note that although the halfway house 
and therapeutic community (TC) approaches for substance dependence rehabilitation share similar concepts and philosophies, their treatment modalities differ. ${ }^{6}$

Therapeutic communities were systematically reviewed by Smith et al. (2006) to determine the effectiveness of TCs versus other treatments for substance dependence and to investigate whether their effectiveness is moderated by patient or treatment characteristics. The authors concluded that there is little evidence that TCs offer significant benefits in comparison with other residential treatment or that one type of TC is better than another. ${ }^{18}$

A halfway house, "dry house" or "sober house" is defined as a more accessible transition between hospitalization and life in the community. Its objective is to promote a social support system for alcohol and substance dependents who will benefit from the supportive treatment structure in such a sober environment. ${ }^{19}$

The main philosophical construct informing this kind of substance abuse treatment program has been the social or community model approach, which gained strength in the 1980s and became embodied by a continuum of recovery services. These models are publicly funded, legally incorporated nonprofit organizations with a heavy emphasis on the community and social environment, the importance of assumption, knowledge and practice to the recovery process, staff-client interactions, and on the importance of employing staff who are in recovery. ${ }^{5,6}$ Such a model can allow the patients to begin the process of reintegration with society while still providing monitoring and support; this is generally believed to reduce the risk of relapse as compared to direct discharge into society. ${ }^{20,21}$

The treatment diversity offered in these services is very wide. Some include informal treatment and others adopt a 12-step model. The programs, in general, are exclusively for either men or women and it is rare for both genders to be treated in the same program. Program duration varies between one and 320 days. Patients who reside for a longer period of time tend to better reintegrate into society and decrease their likelihood of substance abuse after discharge. ${ }^{20}$

Some programs focus on introducing the basic concepts of self-care (e.g., maintaining the house, exercise, basic meal preparation) as well as developing money management skills (projecting weekly expenses) and working to understand past actions and how they affected the resident's life both positively and negatively. ${ }^{6,22}$

Studies aiming to evaluate the effectiveness of this treatment modality have identified many methodological issues. The main concerns are the paucity of a control group, intervention variations and outcome analysis, the small sample size, and the reliability of the results obtained. However, they typically report favorable results and show that this approach tends to increase compliance to outpatient treatment. ${ }^{19,23}$

Studies conducted by Annis \& Liban (1979), Ryswyk (1981), Booth (1981), Walker (1982), Baskin (1983), Huselid (1991), Fischer (1996), Davis (2005), and Jason (2007) indicated positive outcomes to treatments offered by various halfway houses. The main positive outcomes were: 1) lower detoxification admission index, 2) lower use of public assistance services, 3) lower involvement with criminal justice or prisons, 4) higher employment commitment after discharge, 5) lower admission to emergency hospitals, 6) lower medical and legal costs to the public, 7) more humanitarian system, 8) a higher degree of satisfaction among residents, 9) lower system costs, and 10) improvement in abstinence levels..$^{20,24-28}$ It was also possible to identify negative outcomes, including a younger population (under the age of 25) and use of multiple drugs associated with primary alcohol use. ${ }^{27,30}$

According to Pekarik \& Zimmer (1992), this model has an average annual cost of US $\$ 2900.00$ in the USA. ${ }^{31}$

In Brazil, a network of assistance for substance dependence has been built from a variety of public and private facilities that comprise various care levels, including: specialized outpatient treatment, primary care centers, general hospitals, halfway housing, clinics, drug and alcohol psychosocial attention centers, self-help groups, therapeutic communities and harm reduction programs. ${ }^{17,32,35}$ Psychiatric hospitals continue to be a treatment option in certain cases in the decentralized network system. ${ }^{36}$

Despite being considered into the tertiary level of attention, ${ }^{32}$ we observe in Brazil a lack of therapeutic residences for psychoactive substance users. An adequate halfway house approach employing the therapeutic tradition model for substance users does not exist.

The diversity of facilities associated with treatment structure plurality, which addresses the complexity of patients' problems (physical and mental health, social, family, professional, marital, motivational stage, etc.) seems to guarantee the success of the care model proposed for substance users. ${ }^{32,35,36}$

\section{National and international experiences}

The Oxford House System, founded in Maryland, USA in October of 1975, is a non-governmental organization (NGO) which presently accounts for more than 20 residences in many cities. The central principle of Oxford House is to stimulate recovery and provide housing for alcohol dependents who desire to cease alcohol use and live in sobriety, this being the major requirement to program inclusion and participation. ${ }^{37}$ The system is not run for profit, 
and every residence is independently and self-sufficiently managed by the residents themselves. However, there is a set of operative norms and traditions created by democratic vote. The system also employs a non-professional staff, although outside professionals may be hired in special situations. The Oxford House is not connected to Alcoholics Anonymous (AA), but supports resident participation in AA meetings. ${ }^{37}$

Over the past 12 years, a university research team has been involved in a collaborative action research project with a community-based, self-run, residential substance abuse recovery program at Oxford House. ${ }^{29}$ Spirituality was evaluated among residents in one of the Oxford Houses; moreover, it was found that $76 \%$ participate in AA meetings weekly. It also seemed that building a social network beyond the walls of the residence is an essential factor in recovery. A two year follow-up study which evaluated 130 patients in the Oxford House system indicated positive results as relates to psychoactive substance abstinence. . $^{37,38}$

Jason et al. (2007) observed 150 individuals discharged from residential substance abuse treatment, including at Oxford House, in a 24-month follow-up study. Their findings suggest that there was a decrease in substance abuse for residents who lived in Oxford Houses for six or more months (15.6\%), compared both to participants residing in Oxford House for less than six months (45.7\%) and to participants assigned to the usual after-care condition (64.8\%). Results also indicated that both older residents and younger residents living in a house for six or more months experienced better outcomes in terms of substance use, employment and selfregulation. ${ }^{30}$

\section{The Halfway House in Jardim Angela, in the city of São Paulo/SP, Brazil}

A halfway house service was operated from late 1999 to September 2003 in the outskirts of Sao Paulo, an area known for its high exclusion and homicide index (122 per 100 thousand inhabitants in 1995). ${ }^{40}$ Technical and financial support came from UNIFESP/UNIAD, the state public health and a Catholic NGO that had been in the community more than 12 years.

This community, with its high violence indices, had an average of one outlet for every 12 homes, which suggested as a hypothesis the potential of an association between a lack of culture and leisure centers and alcoholism and violence. ${ }^{41}$ The neighborhood was reported to be the most violent region in the world by the United Nations in the late 1990s. ${ }^{40}$

The Jardim Angela Halfway House had a 10-bed capacity, and alcohol dependents' stays were limited to 30 days. It served 130 patients from October 1999 to November 2001.
The service's aim was to become a communitarian, temporary home facility supported mainly by nonspecialized staff and/or alcohol dependents in recovery. The home atmosphere emphasized obtaining health, self respect and binding social support network systems through abstinence. A psychological sense of community provided a sense of belonging, identity, emotional connection and well-being. ${ }^{42}$

Patients were under the care of a communitarian agent 24 hours a day. Agents assisted patients with meals (prepared by the residents with the help of a cook, who was undergoing a longer recovery process), personal hygiene, physical company, developing activities and games, as well as supervision of family visits and phone calls.

Residents received psychiatric, psychological, nurse and social assistance one or two times a week in an outpatient service center located close to the residence. Volunteers from the community led activities involving arts and crafts, horticulture, ceramics and yoga therapy. The residents also went to church if they wished and walked in the morning, accompanied by agents.

The cost per resident was about US $\$ 13.00$ per day, with meals, medications and all amenities included. Funds received through donations from community volunteers notwithstanding, this project could not be continued due to financial difficulties in maintaining the house brought on by the end of its sponsorship and lack of a budget.

Today, an infirmary with 10 beds exists in the same house. This service was inaugurated in 2006 and is supported by the local government. A full-time communitarian agent is present.

Similar initiatives may exist in other places in Brazil; however, this has not been documented in scientific literature.

\section{DISCUSSION}

\section{Limitations}

The evidence of a narrative review is limited when compared to other study methods, such as systematic reviews. Such narratives can involve the a possibility of bias, mainly regarding selection bias. ${ }^{43}$ However, data resulting from narratives is important to add to the available information about halfway house success, which remains relative unexplored in Brazil.

\section{Implications for substance user-service organizations}

The therapeutic residence model currently designated for psychoactive substance users seems to be a low-cost service 
option. Further, it offers dignity to the patients while building social support in a self-help network system, yielding broad changes in favor of living in sobriety. ${ }^{21,31} 38,39$

Positive outcomes seem to be linked to respect for institutional traditions among resident members: for example, promotion of abstinence requirement (whether in or out of the residence) and the setting of residence permanence goals. ${ }^{37}$ To achieve such outcomes, it is necessary to guarantee continuity in the support process with reinforcement from governmental actions. Thus, we may infer that the positive outcomes achieved by Oxford House stem from its having been aligned with national policies since 1988; these policies promoted expansion of the rehabilitation home network. ${ }^{37}$

The level of private and public sector inpatient substance abuse services has been reduced under modern managed care. Compounding this problem is the fact that various traditional substance abuse treatment programs, including inpatient and outpatient treatment programs, have high relapse rates. This is evidence of the need to develop and evaluate lower cost, non-medical, community-based care options for individuals recovering from substance-related disorders. ${ }^{39}$

\section{Implications for future studies}

We hope that other studies on this topic consider a more consistent and relevant way to address questions about the eligibility criteria, effectiveness and efficiency of this approach for substance users. Due to a lack of national studies on therapeutic residences in Brazil, we suggest that this area is in need of future research.

\section{ACKNOWLEDGEMENT}

To Father Jaime Crowe, president of the Sociedade Santos Martires, for envisioning that his religious role extends beyond the borders his church.

\section{REFERENCES}

1. Budson RD. The Psychiatric Halfway House. A Handbook of Theory and Practice. $1^{\text {a }}$ ed. Pittsburg: University of Pittsburg Press; 1978. p.278.

2. Golomb SL \& Kocsis A. The Halfway House. On The Road to Independence. $1^{\text {a }}$ ed. Brunner/Mazel Publishers: New York, 1988. p.256.

3. Vidal CEL. Avaliação das Habilidades de vida independente e comportamento social de pacientes psiquiátricos. [Dissertação]. Belo Horizonte (MG): Universidade Federal de Minas Gerais. 2007.

4. Minuchin S. Família Funcionamento e Tratamento.Porto Alegre: Artmed. 1990.

5. De Leon G. The Therapeutic Community Treatment Model. IN McCrady BS \& Epstein EE. Addictions: A comprehensive guidebook. IN: Oxford University Press: New York; 1999. p.306-27.

6. De Leon G. A Comunidade terapêutica. Teoria, Modelo e Método. $1^{\mathrm{a} e d .}$ Editora Loyola; 2003.

7. Araújo A. Residential Therapeutic Mental Health Services: an ethnographic study on group homes of Campinas - SP. [Dissertação]. Vitória (ES): UFES. 2004.

8. Girolamo G \& Picardi A. Residential care in Italy: National survey of non-hospital facilities. British Journal of Psychiatry. 2002,181:22025 .

9. Vidal CEL, Vidal LM, Fassheber V. Residência terapêutica: uma nova modalidade de cuidados em saúde mental. A experiência de Barbacena. Cadernos IPUB, Rio de Janeiro. 2006; 12:155-61.
10. Andreoli SB, Almeida- Filho N, Martin D, Mateus MDML, Mari JJ. Is psychiatric reform a strategy for reducing the mental health budget? The case of Brazil. Rev. Bras. Psiquiatr. 2007;29:43-46.

11. Ministério da Saúde. Secretaria de Atenção à Saúde. Departamento de Ações Programáticas Estratégicas. Residências terapêuticas: o que são, para que servem / Ministério da Saúde, Secretaria de Atenção à Saúde, Departamento de Ações Programáticas Estratégicas. - Brasil-Brasília: Ministério da Saúde, 16 p. il. - (Série F. Comunicação e Educação em Saúde), 2004

12. Jaegger RC, Guitton AP, Lyrio JM, Santos MM, Freitas RCO, Gonçalves SRL et al. A experiência de morar fora: avaliação da satisfação de usuários em um serviço de saúde mental. Cadernos Saúde Coletiva, Rio de Janeiro. 2004;12:27-39.

13. Menikoff A. Psychiatric Home Care. Clinical and Economic Dimensions. Academic Press: London; 1999.p.288.

14. Jacob KS, Sharan P, Mirza I, Garrido-Cumbrera M, Seedat S, Mari JJ, et al. Mental health systems in countries: where are we now? Lancet. 2007;22;370:1061-77.

15. Zago Ma. A Pesquisa clínica no Brasil. Ciênc. Saúde coletiva. 2004;9:363-74.

16. Gentil V. More for the same? Rev Bras Psiquiatr. 2007;29:188-99.

17. Cordeiro DC \& Baldaçara L. Emergências Psiquiátricas IN: O Pronto Socorro, o Sistema Único de Saúde e as Políticas de Saúde. Rita Jorge. Editora Roca, São Paulo, p. 263-72. 
18. Smith LA, Gates S, Foxcroft D. Therapeutic communities for substance related disorder. Cochrane Database of Systematic Reviews 2006, Issue 1. Art. No.: CD005338. DOI: 10.1002/14651858.CD005338.pub2.

19. Polcin DL. Sober living houses: potential roles in substance abuse services and suggestions for research. Subst Use Misuse. 2001;36:30111.

20 Booth R. Alcohol Halfway Houses: Treatment Length and Treatment Outcome. The International Journal of Addictions. 1981;16:927-34.

21. Anderson DJ. Delivery of Essential Services to Alcoholics through the "Continuum of Care". Cancer Research. 1979;39:2855-58.

22. Walker K, Sanchez-Craig M, Bornet A. Teaching Coping Skills to Chronic Alcoholics in a Coeducation Halfway House: II. Assessment of Outcome and Identification of Outcome Predictors. British Journal of Addictions. 1982;77:185-96.

23. Moos RH \& Moos BS. Stay in Residential Facilities and Mental Health Care as Predictors of Readmission for Patients with Substance Use Disorders. Psychiatric Services. 1995,46:66-72.

24. Annis HM, Liban CB. A follow-up study of male halfway-house residents and matched nonresident controls. J Stud Alcohol. 1979;40:639.

25. Ryswyk CV; Churchill M, Velasquez J, Mcguire R. Effectiveness of Halfway House Placement for Alcohol and Drug Abusers. American Journal of Drug Alcohol Abuse. 1981-82;8:499-512.

26. Baskin D, Missouri C. A Treatment Outcome Study of Alcohol Halfway House Residents in the South Bronx. The International Journal of the Addictions. 1983;18:551-58.

27. Huselid RF, Self EA, Gutierres SE. Predictors of successful completion of a halfway-house program for chemically-dependent women. Am J Drug Alcohol Abuse. 1991;17:89-101.

28. Fischer EH. Alcoholic patients' decisions about halfway houses. What they say, what they do. J Subst Abuse Treat.1996;13:159-64.

29. Davis MI, Jason LA, Ferrari JR, Olson BD, Alvarez J. A Collaborative Action Approach to Researching Substance Abuse Recovery. The American Journal of Drug and Alcohol Abuse. 2005;31:537- 53.

30. Jason LA, Olson BD, Ferrari JR, Majer JM, Alvarez J, Stout J. An examination of main and interactive effects of substance abuse recovery housing on multiple indicators of adjustment. Addiction. 2007;102:111421.
31. Pekarik G \& Zimmer L. Relation Client Variables to Continuance in Five Types of Alcohol Treatment Settings. Addictive Behaviors. 1992;17:10515.

32. Diretrizes para um modelo de assistência integral em saúde mental no Brasil. Associação Brasileira de Psiquiatria (ABP) 2006. p.58. Disponível em URL: www.abpbrasil.org.br/diretrizes_final.pdf. Acesso em 15/03/2007.

33. Focchi GRA, Leite MC, Laranjeira R, Andrade A. Dependência Química: Novos Modelos de Tratamento. 1ª ed. São Paulo: Roca; 2001. p.165.

34. Botega NJ. Prática psiquiátrica no hospital geral: interconsulta e emergência. IN: Psiquiatria no hospital geral: histórico e tendências. Neury José Botega. $2^{\mathrm{a}}$ ed. Porto Alegre:Artmed. 2006.

35. Cordeiro DC, Figlie NB, Laranjeira R. Boas Práticas no Tratamento do uso e Dependência de Substâncias.IN: Capítulo 2: Organização de Serviços para o Tratamento do Uso Nocivo e Dependência do Álcool. Marcelo Ribeiro.Roca. 2007, p. 6-12.

36. Cruz MS. Internação Versus Tratamento Ambulatorial. IN: da Silveira DX \& Moreira FG. Panorama Atual de Drogas e Dependências. Editora Atheneu. 2006.p.113-22.

37. Manual de la Oxford House. Una idea basada en un sistema seguro para la rehabilitación de alcohólicos que se auto-ayudan. Oxford House, Inc., Arlington, Virginia, Trans Text; 1990

38. Nealon-Woods MA, Ferrari JR, Jason LA. Twelve-step program use among Oxford House residents: spirituality or social support in sobriety? J Subst Abuse. 1995;7:311-8.

39. Jason La, Olson Bd, Ferrari Jr, Davis Mi. Substance Abuse: The Need For Second-Order Change. International Journal of Self Help and Self Care. 2(2) / 2003-2004. 91-109.

40. Relatório de Cidadania - Os Jovens e os Direitos Humanos. Rede de Observatórios de Direitos Humanos. Rev Saúde Pública. 2002;36:45561.

42. Fisher AT, Sonn CC, BJ. Psychological Sense of Community: Research, Applications, and Implications. Series Editor: CR Snyder University of Kansas Lawrence, Kansas..2002.p.339.

43. Everitt BS \& Wesseley S. Clinical Trials in Psychiatry. IN Systematic reviews and meta-analysis. Oxford University Press London. 2003. p121-35. 